\title{
PERAN E-WOM DAN CITRA MEREK TERHADAP NIAT BELI SMARTPHONE OLEH YOUTUBE VIEWERS
}

\author{
Muhammad Baiquni \\ Universitas Negeri Surabaya \\ muhammadbaiquni@mhs.unesa.ac.id
}

\begin{abstract}
Smartphones in today's era are a basic necessity especially for those who have high mobility. No less advanced than technological developments, innovation in the telecommunications world is also one of the biggest contributors to the dissemination of information in society or commonly called social media. This study aims to measure the influence of Electronic Word of Mouth (e-WOM) that occurs in YouTube social media on the intention to buy Samsung Galaxy S1O smartphones through the brand image as a mediating variabel. The type of method used in this research is quantitative by using Path Analysis. This study has positive results between influences eWOM on the purchase intention, while there was a positive influence between e-WOM on the brand image variabel and the brand image variabel had a positive effect on the purchase intention. Further research may include price and product quality.
\end{abstract}

Keywords: brand image; electronic word of mouth; purchase intention.

\section{PENDAHULUAN}

Smartphone merupakan industri paling dinamis di dunia dan evolusinya terkait erat dengan pembaharuan teknologi. Selain evolusi teknologi, semakin banyak konsumen yang terpapar dengan penggunaan internet tanpa menghiraukan tujuannya. Beberapa masyarakat menggunakannya untuk hiburan sementara yang lain menggunakannya untuk meningkatkan produktivitas. Terlepas dari semua itu, sebagian kelompok masyarakat memanfaatkan internet sebagai sumber referensi dalam memilih produk yang akan di konsumsi (Sharinaz, 2016).

Pertumbuhan pasar smartphone di Indonesia sangat pesat dari data yang diperoleh pada tahun 20162019 pengguna smartphone di Indonesia meningkat 65,2 juta menjadi 92 juta pengguna (International Data Corporation, 2019). Dari banyaknya merek smartphone yang tersebar di Indonesia, Samsung menduduki posisi teratas dalam penjualan ponsel pintar di Indonesia yang berhasil menjual 8-9 juta smartphone. Akan tetapi jika dilihat dari kerusakannya Samsung juga menduduki peringkat teratas dengan tingkat kerusakan smartphone sebesar 27,4 \% (Kumparan, 2019).

Dari banyaknya pengguna smartphone di Indonesia terdapat banyak cara yang dilakukan oleh pemasar seperti menggunakan jasa YouTuber atau akrab disebut dengan content creator. Dengan mengirimkan produk mereka untuk diulas secara gamblang tanpa melebih-lebihkan produk tersebut karena mereka membutuhkan reputasi untuk channel mereka (GadgetIn, 2019).

Jalilvand (2012) telah melakukan penelitian dalam sebuah komunitas virtual pada media sosial Facebook yang menunjukkan bahwa terdapat pengaruh positif Electronic Word of Mouth(e-WOM) terhadap niat beli dan citra merek. Penelitian tersebut belum menjelaskan apakah e-WOM yang disampaikan dari media sosial tanpa komunitas/ grup tertentu dapat memperoleh hasil yang sama.

Penelitian ini bertujuan menganalisis pengaruh e-WOM yang disampaikan melalui media sosial YouTube berpengaruh terhadap niat beli melalui citra merek sebagai variabel mediasi. Penelitian dilakukan pada media sosial YouTube dari channel yang membahas atau mengulas produk Samsung Galaxy S10. 
Muhammad Baiquni. Peran E-WOM dan Citra Merek terhadap Niat Beli Smartphone oleh Youtube Viewers

\section{KAJIAN PUSTAKA DAN PENGEMBANGAN HIPOTESIS}

\section{Electronic Word of Mouth}

Menurut Turban, et al (2015) Word of Mouth (WOM) dapat memengaruhi konsumen dalam berperilaku yang dimasukkan kedalam influential factors yang terdalamnya berisi faktor lingkungan yang dapat memengaruhi konsumen. WOM merupakan bentuk komunikasi positif dan negatif yang dilakukan oleh konsumen yang memiliki pengalaman pembelian Thurau, et al., (2004). Seiring berkembangnya teknologi dalam saluran komunikasi WOM berubah menjadi Electronic Word of Mouth (e-WOM). Menurut Tjiptono (2011:315) $e$-WOM merupakan bentuk komunikasi yang didirikan oleh konsumen yang disebut Consumen Generated Media atau bisa juga disebut Viral Marketing yang merupakan bagian dari demokratisasi media oleh konsumen melalui berbagai media di antaranya Blog, Podcasting, Wiki, Public Messanger Boards, Social Networks, Product Reviews Sites.

\section{Niat Beli}

Menurut Engel F, Blackwell, \& Miniard (2000;200) terdapat lima langkah sebelum konsumen menetapkan keputusan pembelian di antaranya tahap pertama merupakan tahapan di mana konsumen melakukan pengenalan terhadap masalah, tahap kedua merupakan tahapan di mana penelusuran informasi dibutuhkan untuk menggali lebih dalam tentang suatu produk, tahapan ketiga yaitu evaluasi alternatif di mana konsumen menyudutkan pilihan dari beragam alternative produk yang ada, tahap keempat yaitu memilih produk atau mengkonsumsi produk yang telah dipiliih, dan tahap akhir merupakan hasil dari mengkonsumsi produk tersebut. Sedangkan penelitian yang digunakan terdapat pada tahap ketiga yaitu evaluasi alternative yang dikatakan sebagai tahap mengevaluasi dari berbagai macam pilihan yang sudah disempitkan sehingga dapat memenuhi kebutuhan dan keinginan yang diharapkan oleh konsumen sebelum melakukan pembelian.

\section{Citra Merek}

Menurut Aaker (1997;164), asosiasi merek dapat menyodorkan konsumen alasan yang spesifik untuk membeli dan menggunakan produk tersebut. Asosiasi-asosiasi inilah yang menjadi landasan untuk membuat keputusan pembelian. citra merek juga menjadi alasan konsumen untuk memilih produk. Schiffman dan Kanuk $(2008 ; 127)$ pada umumnya konsumen memilih merk yang memiliki citra dan kepribadian sehingga menghindari produk yang tidak sesuai.

Menurut Tjiptono (2008:49) dalam Pramughita (2016), citra merek merupakan deskripsi produk yang berasal dari keyakinan konsumen. Dalam penelitian yang membahas citra merek dapat menggunakan teknik kuantitatif dan kualitatif yang saat ini telah dikembangkan untuk menyelidiki deskripsi dari merek yang dimiliki konsumen di antaranya multidimensional scaling, projection techniques, dan sebagainya. Menurut Rangkuti (2009:244), citra merek sebagai kumpulan asosiasi yang tertanam dalam ingatan masyarakat diperoleh dari pengalaman menggunakan produk maupun jasa.

\section{Hubungan antar Variabel}

Jalilvand (2012) mengamati sebuah komunitas virtual di dalam platform media sosial Facebook tempat konsumen menyebarkan pengalaman produk atau layanan mereka memiliki dampak positif terhadap niat pembelian dan $e-W O M$ juga memiliki pengaruh positif terhadap citra merek. Penelitian yang dilakukan oleh Michelle (2018) yang secara langsung menghubungkan $e$-WOM terhadap niat beli juga memiliki hasil yang signifikan sedangkan penelitian yang dilakukan oleh Sharinaz (2016) memiliki hasil yang bertolak belakang, $e$-WOM yang disebarkan melalui platform media sosial Facebook tidak memiliki dampak yang langsung terhadap niat beli.

H1: $\quad e-W O M$ berpengaruh positif terhadap niat beli Samsung Galaxy S10.

$\mathrm{H} 2: \quad e-W O M$ berpengaruh positif terhadap citra merek Samsung Galaxy S10.

H3: Citra merek berpengaruh positif terhadap niat beli Samsung Galaxy S10. 


\section{METODE PENELITIAN}

Metode penelitian yang akan dipakai dalam penelitian ini menggunakan berjenis kausal. Penelitian ini merupakan studi pengujian pasar sehingga memerlukan 200 sampel (Malhotra, 2017:369). Dari total keseluruhan sebanyak 200 sampel dan ditambahkan $10 \%$ menjadi 220 yang bertujuan untuk berjagajaga apabila terdapat kesalahan dalam pengisian angket. Teknik penarikan sampel bersifat non probability sample dengan metode purposive, Alasan mengguanakan metode ini karena infomasi yang didapatkan diperoleh dari kelompok sasaran tertentu yang dikehendaki. Angket dibuat menggunakan Google Form dan disebarkan melalui kolom komentar pada video yang membahas tentang Samsung Galaxy S10 pada media sosial YouTube.

\section{HASIL DAN PEMBAHASAN}

\section{Deskripsi Responden}

Responden penelitian ini berjumlah 220 orang yang berasal dari 54,1 persen laki-laki dan 45,9 persen perempuan yang merupakan viewers media sosial YouTube yang mereview Samsung Galaxy S10 di Indonesia. Berdasarkan data yang terhimpun diketahui stastus pekerjaan mereka sebagai Mahasiswa sebanyak 12 orang, sebagai Pegawai Negeri Sipil (PNS) sebanyak 61 orang, sebagai karyawan swasta sebanyak 69 orang, sebagai pengusaha sebanyak 59 orang dan profesi lainnya sebanyak 19 orang.

Dalam hasil uji multivariate diperoleh hasil sebesar 1,083 yang merupakan dalam rentang -2,58-2,58. Hasil uji ini membuktikan bahwa uji multivariate normality dinyatakan lolos uji. Hasil uji linearitas dari variabel $e-W O M$, citra merek, dan niat beli sebesar $0,00<0,05$ dari hasil dapat diketahui bahwa uji linearitas sudah terpenuhi. Hasil uji outliers juga sudah memenuhi karena memiliki nilai mahalanobis distance tertinggi 16,07 yang lebih rendah dari 16,27.

\section{Uji Validitas Item}

Dari keseluruhan item memiliki hasi valid baik variabel X maupun variabel Y dan Z. Hal ini karena semua $\mathrm{T}_{\text {Hitung }}$ lebih besar daripada $\mathrm{T}$ Tabel $(0,361)$ untuk $\mathrm{N}=220$.

\section{Uji Normalitas Item}

Dilihat pada tabel di bawah diperoleh hasil nilai pada kolom c.r dan nilai skew dari setiap variabel dapat dinyatakan berdistribusi normal karena nilai berada di range -2,58 sampai 2,58. Sedangkan uji normalitas multivariate adalah sebesar 1,083 yang berada dalam rentang -2,58 hingga 2,58, dari hasil uji normalitas dapat dinyatakan bahwa data dapat dilanjutkan dalam perhitngan selanjutnya.

Tabel 1. HASIL UJI NORMALITAS

\begin{tabular}{ccccccc}
\hline Variabel & Min & Max & Skew & c.r. & Kurtosis & c.r. \\
\hline Electronic Word of Mouth & 3 & 4.87 & -0.096 & -0.583 & -0.518 & -1.569 \\
Citra Merek & 2.93 & 4.87 & -0.186 & -1.127 & 0.37 & 1.12 \\
Niat Beli & 3 & 5 & -0.077 & -0.464 & -0.52 & -1.575 \\
Multivariate & & & & & 0.8 & 1.083 \\
\hline
\end{tabular}

Sumber: Data diolah (2019)

\section{Uji Koefisien Determinasi}

Dari tabel 2, dapat dilihat hasil dari nilai koefisien determinasi $\left(\mathrm{R}^{2}\right) e-W O M$ terhadap citra merek $\left(\mathrm{R}^{2} 1\right)$ sebesar 0,027 sedangkan hasil nilai koefisien determinasi dari variabel citra merek terhadap niat beli $\left(\mathrm{R}^{2} 2\right)$ sebesar 0,274. Hasil statistik tersebut dapat dituliskan dalam rumus (1).

Dilihat dari kalkulasi ketepatan model di atas adalah sebesar 70,63\% hal tersebut menegaskan bahwa hubungan structural dari keseluruhan variabel memiliki kontribusi sebesar 0,7063 (70,63\%) yang memiliki arti bahwa variabel independent $e$-WOM memenuhi sebagai sumber informasi variabel dependen niat beli. 
Muhammad Baiquni. Peran E-WOM dan Citra Merek terhadap Niat Beli Smartphone oleh Youtube Viewers

$$
R^{2} \text { model }=1-(1-0,027)(1-0,274)
$$

\section{Tabel 2. HASIL UJI KOEFISIEN DETERMINASI}

\begin{tabular}{cc}
\hline Variabel & Estimate \\
\hline Citra Merek (Z) & 0.027 \\
Niat Beli (Y) & 0.274 \\
\hline
\end{tabular}

Sumber: Data diolah (2019)

Setelah melakukan uji rangkaian di atas selanjutnya dapat dilakukan uji Path Analysis dengan hasil yang dapat dilihat di Gambar 1. Dilihat dari gambar jalur diagram dapat diketahui bahwa terdapat hasil yang positif antara variabel $e$-WOM terhadap variabel niat beli dengan nilai koefisien jalur sebesar 0,1 . Jalur kedua juga memiliki hasil yang positif yaitu pengaruh variabel $e$-WOM terhadap variabel citra merek dengan nilai koefisien jalur sebesar 0,164. Jalur yang terakhir juga mendapat hasil yang positif pada variabel citra merek terhadap variabel niat beli dengan nilai koefisien jalur sebesar 0,498.

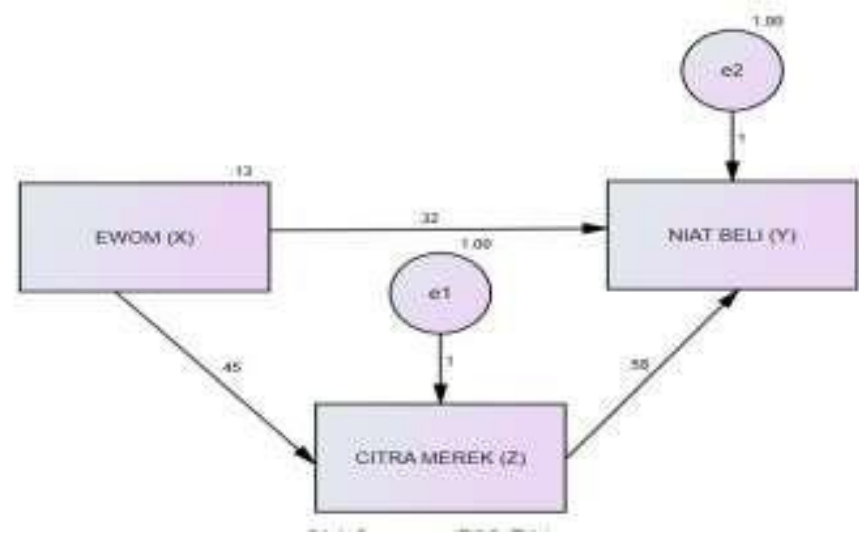

Sumber: Data diolah (2019)

\section{Uji Hipotesis}

Gambar 1. JALUR DIAGRAM

Dari tabel dapat dilihat hasil uji hipotesis melalui nilai C.R dan signifikansinya. Hipotesis pertama memiliki nilai C.R 1,484<2,00 dan memiliki nilai probabilitas signifikansi sebesar 0,138 ( $\mathrm{p} \leq 0,05)$. Hipotesis pertama ditolak atau tidak terdapat pengaruh positif antara variabel $e$-WOM terhadap niat beli karena memiliki nilai di bawah signifikansi. Untuk melihat hasil hipotesis kedua dapat dilihat nilai C.R sebesar 2,466 $\geq 2,00$ dengan nilai probabilitas signifikansinya sebesar $0,014(\mathrm{p} \leq 0,05)$. Hipotesis kedua diterima atau variabel $e-W O M$ berpengaruh signifikan terhadap variabel citra merek. Hasil dari hipotesis ketiga dapat dilihat nilai C.R. sebesar 2,307 $\geq 2,00$ dan nilai probabilitas signifikansi sebesar $0,021(\mathrm{p} \leq 0,05)$. Hipotesis ketiga diterima atau variabel citra merek berpengaruh signifikan terhadap nat beli.

\section{Tabel 3. HASIL UJI HIPOTESIS}

\begin{tabular}{ccccc}
\hline Variabel & Estimate & S.E. & C.R. & P \\
\hline$e-W O M(X) \rightarrow$ Niat Beli $(Y)$ & 0.322 & 0.217 & 1.484 & 0.138 \\
$e-W O M(X) \rightarrow$ Citra Merek $(\mathrm{Z})$ & 0.455 & 0.185 & 2.466 & 0.014 \\
Citra Merek $(\mathrm{Z}) \rightarrow$ Niat Beli $(Y)$ & 0.577 & 0.25 & 2.307 & 0.021 \\
\hline
\end{tabular}

Sumber: Data diolah (2019)

\section{Pengaruh $e$-WOM terhadap Niat Beli}

Berdasarkan hasil analisisis yang dilakukan, hal ini menunjukkan bahwa tidak terdapat hasil signifikan antara variabel $e-W O M(X)$ terhadap variabel niat beli $(\mathrm{Y})$ atau hipotesis pertama ditolak. Menurut Sharinaz (2016) mengatakan bahwa $e$-WOM tidak memiliki hasil pengaruh terhadap variabel niat beli. Tetapi menurut Jalilvand (2012) dan penelitian yang dilakukan oleh Lin (2013) yang menunjukkan hasil $e-W O M$ berpengaruh terhadap niat beli. 
Jika dikaitkan dengan karakteristik responden yang dominan dengan gender laki-laki yang artinya lakilaki lebih memiliki sifat berhati-hati sebelum membulatkan tekad untuk memilih Smartphone Samsung Galaxy S10 sebagai ponsel penunjang aktivitas mereka.

Para pembuat merupakan aktor dalam informasi konsumen dan mereka selalu mengupdate dan mengganti ponsel mereka sesuai kebutuhan konten. Akan tetapi membeli sebuah smartphone membutuhkan banyak pertimbangan dibandingkan dengan produk umum sehingga konsumen akan mempertimbangkan untuk memilih kualitas produk, atau harga yang sesuai dengan kemampuan mereka.

\section{Pengaruh $e$-WOM terhadap Citra Merek}

Penelitian ini menunjukkan hasil yang signifikan antara $e-W O M(\mathrm{X})$ terhadap variabel mediasi citra merek (Z). Hal tersebut mengindikasikan bahwa $e$-WOM yang disampaikan para pembuat konten melalui media sosial YouTube dapat membentuk citra dari smartphone Samsung Galaxy S10 serta mendukung hipotesis kedua yaitu terdapat pengaruh positif antara $e$-WOM terhadap citra merek.

Menurut Yunus (2016) dan Charo, et al., (2015) menunjukkan hasil signifikan antara $e$-WOM dengan citra merek. Tetapi Kumoro (2014) mengatakan bahwa $e$-WOM tidak berpengaruh terhadap citra merek. Jika dikatikan dengan karakteristik responden dengan gender laki-laki artinya informasi yang diterima oleh responden akan membentuk sebuah citra merek dari Samsung Galaxy S10 yang kuat.

\section{Pengaruh Citra Merek terhadap Niat Beli}

Hasil penelitian ini menunjukkan pengaruh yang signifikan antara citra merek (Z) dengan niat beli (Y) atau menerima hipotesis ketiga. Yang berarti semakin banyak asosiasi merek yang di dapatkan maka hasrat penonton untuk membeli Samsung Galaxy S10 juga semakin meningkat. Menurut Torlak, et al., (2014) yang menunjukkan hasil yang signifikan antara citra merek dan niat beli. tetapi Pramudya (2017) mengatakan bahwa citra merek tidak memiliki pengaruh terhadap niat beli.

Uji mediasi juga membuktikan bahwa variabel citra merek berperan sebagai penghubung antara variabel dependen terhadap independen karena variabel $e$-WOM terhadap niat beli tidak memiliki pengaruh yang signifikan.

Jika dilihat dari karakteristik responden dengan gender laki-laki dan bekerja sebagai karyawan swasta memiliki ketertarikan untuk membeli Samsung Galaxy S10 dengan asumsi ponsel tersebut dapat menunjang aktivitas mereka maupun untuk memenuhi gaya hidup mereka.

\section{KESIMPULAN}

Tidak ada pengaruh signifikan $e$-WOM terhadap niat beli. Terdapat pengaruh signifikan $e$-WOM terhadap citra merek dan terdapat pengaruh signifikan citra merek terhadap niat beli. Keterbatasan penelitian ini adalah penyebaran angket hanya menggunakan angket online, sehingga sangat mungkin terjadinya kecurangan seperti pengisian angket lebih dari 1 kali oleh responden yang tidak dapat teridentifikasi. Maka pada penelitian selanjutnya diharapkan untuk menggunakan angket secara online dan offline. Penelitian selanjutnya dapat melibatkan variabel customer generated content, buzz, atau advergaming.

\section{DAFTAR PUSTAKA}

Aaker, David A. 1997. Manajemen Ekuitas Merek. Terjemahan: Aris Ananda. Jakarta: Spektrum.

Abdallah Q. Bataineh. (2015). The Impact of Perceived $e W O M$ on Purchase Intention: TheMediating Role of Corporate Image. International Journal of Marketing Studies; Vol. 7, No. 1; ISSN 1918719X E-ISSN 1918-7203 
Muhammad Baiquni. Peran E-WOM dan Citra Merek terhadap Niat Beli Smartphone oleh Youtube Viewers

Cheung, M.K., Dimple, R. (2012). The impact of electronic word of mouth communication: A literature analysis and integrative model. Hong Kong

Engel, J. F., Blackwell, R. D., \& Miniard, P. W. (1995). Perilaku Konsumen. Jakarta: Bina Rupa Aksara.

Erkan, I,. Chris, E. (2016). The influence of Electronic Word of Mouth in Social Media on Consumer's Purchase Intention: An Extend approach to information adoption. Computers in Human Behavior, 47-55

David, GadgetIn (2019). (https://www.youtube.com/watch?v=AMH7ypy186o\&t=7s). Diakses pada Mei 2019

Ghozali, I. (2016). Aplikasi Analisis Multivariete Dengan Program IBM SPSS 23 (8 ed.). Semarang, Jawa Tengah: Badan Penerbit Universitas Diponegoro.

Griffin, J. (2005). Customer Loyalty Menumbuhkan \& Mempertahankan Kesetiaan Pelanggan (Revisi dan). Jakarta: Erlangga.

Hennig-Thurau, T.; K. P. Gwinner; G. Walsh dan D.D. Gremler. (2004). Electronic Word-of-Mouth via Consumer-Opinion Platforms: what motivates consumer to articulate themselves on the internet. Journal of interactive Marketing, Vol 18/I/2004, 38-52

International Data Corporation. (2018). (https://www.idc.com/getdoc.jsp?containerId=prA P44263418. Diakses pada juni 2019)

Jalilvand, Mohammad Reza dan Neda Samiei.2012. The Effect of Electronic Word of Mouth on Brand image and Purchase Intention: An empirical study in the automobile industry in Iran. Marketing Intelligence \& Planning. Vol. 30 Iss:4

Kompas.com. 2019. 5 besar pasar Smartphone di Indonesia Counterpoint. (https://tekno.kompas.com/read/2019/03/01/16160037/2018-pasar-smartphoneindonesiatumbuhdua-digit?page=all. Diakses pada 20 Mei 2019)

Kumparan.com. 2019. Ini 5 brands terlaris di Indonesia (https://kumparan.com/kumparantech/ini-5brand-smartphone-terlaris-di-indonesia-1tRJHqAQKrL. Diakses pada 25 Juni 2019)

Kotler, P., \& Keller, K. L. (2009). Manajemen Pemasaran (11 ed.). Jakarta: Erlangga.

Kumoro, Dimas PA. (2015). Pengaruh Dimensi Electronic Word of Mouth Terhadap Faktor-faktor Pembentuk Brand Image.

Lin, Chino., Yi-Shuang, W., Jeng V,C. (2013). Electronic Word of Mouth : The Moderating Roles of Product Involvement and Brand Image. International Conference on Technology Innovation and Industrial Management.

Malholtra, N. K. (2017). Riset Pemasaran (Jilid 1 Ed). Jakarta: Indeks.

Michelle, Yu. (2018) Electronic Word of Mouth Influence on Consumer Purchase Intention. Journal of Fundamental and Applied Sciences; ISSN 1112-9867

Omer., Ozkara, B. Y., Tiltay, M. A., Cengiz, H., \& Dulger, M. F. (2014). The Effect of Electronic Word of Mouth on Brand Image and Purchase Intention: An Application Concerning Cell Phone Brands for Youth Consumers in Turkey. Journal of Marketing Development and Competitiveness, Vol. 8(2), 2014.

Schiffman, L., \& Kanuk, L. L. (2008). Perilaku Konsumen (7 ed.). Jakarta: PT Indeks. 
Sharinaz., Jati Kusuma., Yusman Yacob., Dayang, R., Ahmad F. (2016). Relationship and impact of eWOM and Brand Image towards Purchase Intention. Journal of Scientific Research Development; 3(5):117-124

Sumarwan, U. (2014). Perilaku Konsumen Teori dan Penerapannya dalam Pemasaran (2 ed.). Bogor: Ghalia Indonesia.

Tjiptono, F., \& Chandra, G. (2012). Pemasaran Strategi (2 ed.). Yogyakarta: Andi.

Turban, E., King, D., Lee, J. K., Liang, T.-P., \& C.Turban, D. (2015). Electronic Commerce: A Managerial and Social Networks Perspective (8 ed.). Heidelberg, New York, London: Springer.

Yulian, D,T. (2019). Pengaruh Brand Awareness, Preceived Quality, Dan Kelompok Acuan Terhadap Niat Beli. Surabaya

Yunus, N,H., Shoki, A., Norhuzaimah, Norhayati, Z., Zuraidah, S. (2016). The Meditating Effect of Brand Image between Electronic Word of Mouth and Purchase Intention in Social Media. Advanced Science Letters, Vol 22, 3176-3180

Wardiyastuti, D. (2017). Pengaruh Electronic Word of Mouth Terhadap Niat Beli Konsumen melalui Brand Image. Surakarta 